Scientiae Educatia: Jurnal Pendidikan Sains (2017), Vol 6 (2) : 68-86

DOI: http://dx.doi.org/10.24235/sc.educatia.v6i2.1286

Published by Tadris IPA Biologi, IAIN Syekh Nurjati Cirebon, Indonesia. p-ISSN 2303-1530, e-ISSN 2527-7596

SCIENTIAE EDUCATIA: JURNAL PENDIDIKAN SAINS

journal homepage: www.syekhnurjati.ac.id/jurnal/index.php/sceducatia

www.syekhnurjati.ac.id/jurnal/index.php/sceducatia/article/view/1286

\title{
Profile of Animal Ecology Field trip: Description of Students' Identification Skills and Classification Skills
}

\author{
Iwan Setia Kurniawan $^{a^{*}}$, Fransisca Sudargo Tapilouw ${ }^{\mathrm{b}}$, Topik Hidayat ${ }^{\mathrm{b}}$ \\ a Program Studi Pendidikan Biologi/Universitas Pasundan, Bandung. Indonesia. \\ b Program Studi Pendidikan Biologi, Universitas Pendidikan Indonesia, Bandung, Indonesia \\ ${ }^{\mathrm{x}}$ Corresponding author: Perum GPAA Blok F-13. Sindangpakuon, Cimanggung. Sumedang. Email adresses: iwansetiakurniawan@yahoo.com
}

\begin{tabular}{|c|c|}
\hline articleinfo & Abstract \\
\hline $\begin{array}{l}\text { Article history: } \\
\text { Received: } 27 \text { January } 2017 \\
\text { Received in revised form: } 11 \\
\text { November } 2017 \\
\text { Accepted: } 9 \text { December } 2017 \\
\text { Available online: December } 2017 \\
\text { Keywords: } \\
\text { Animal ecology field trip } \\
\text { Classification skills } \\
\text { Identification Skills } \\
\text { ebird }\end{array}$ & $\begin{array}{l}\text { This study aimed to describe the activities in the field trip of animal ecology course and } \\
\text { describe the identification and classification skills of students at Animal Ecology course. } \\
\text { Also, this study describes students responses on-field activities. This study uses a quasi- } \\
\text { experimental method using only post-test design. Data analysis using quantitative descriptive } \\
\text { analysis techniques. The research subject as many as } 30 \text { students to take the test and } 40 \\
\text { students are given a questionnaire. The results showed that the CPL course and CPL subjects } \\
\text { not relevant to the fact that in both CPL there are some points the use of science and } \\
\text { technology, the reality in the learning process technology, it is also supported by student } \\
\text { response on the issue. The identification and classification skills of students included in the } \\
\text { category sufficient. Analysis of Pearson correlation between the identification and } \\
\text { classification skills showed no significant relationship (-.107), it is contrary to some } \\
\text { assumptions that states that the ability to identify a basis for classification capability. Thus } \\
\text { the results of this study can be used as an input or reference to the development of the } \\
\text { program of courses, especially in the subject of animal ecology. }\end{array}$ \\
\hline
\end{tabular}

2017 Scientiae Educatia: Jurnal Pendidikan Sains

\section{Introduction}

Animal Ecology Lecture is one of the lecture activities that studies the interactivity between animals and their environment. Animal Ecology Lectures are mostly done outside the classroom that we often call field lectures. Field activity is a learning activity that is directly related to nature. With direct field activities students can observe the actual objects in the field, thus providing a good learning experience for students (Thomas, et al., 2017; Surasinghe, et al., 2012; Nelson, et al., 2016). However, field lectures still use many conventional methods without including technological advances. Fieldwork activities should develop with new methods or approaches along with the development of science and technology and the need for scientific progress. Thus, the field trip can provide more innovative new ambience is typically the case. With a new method or approach is students are expected to possess the ability identification and classification skills are good. So far, the method or approach on the field study activities are still using traditional methods. Field trip can be developed to improve 
identification skills of students (Thomas, et al., 2017; Gill, et al., 2015; Penuela, et al., 2016; Friggers, et al., 2015; Robinson, et al., 2016), and classification skills of students (Resheff, et al., 2014; Bom, et al., 2014; Schuld, et al., 2015).

In West Java, so many potential interests that may be targeted for a field trip that focuses on the identification and classification skills, one of which is associated with endemic birds in West Java. The birds are endemic of West Java presence is very concerned and critically endangered, such as the Javan Hawk Eagle, King Prawns, Washed Java, Jays Geling, Caladi stone, Cerecet Java, and others. To overcome the extinction of rare birds endemic of West Java, the necessary conservation efforts. With the field trip that focuses on the identification and classification of the birds, is expected to be one of the references to the conservation of rare bird's endemic of West Java in the future.

Technological advances can be felt so rapidly, especially related to smartphone technology. Various applications can easily be downloaded on available content such as on the Google Play Store or Apps Store. Smartphone applications are very rarely used in supporting learning, more widely used as a means of communication, games, music and entertainment (Thomas, et al., 2017; Beri, et al., 2016; Bouten, et al., 2013). Increasingly sophisticated applications on smartphones can be developed by collaborating with other technology tools such as GPS, geolocator, accelerometer, microarray gene chips, biologists and even now many outstanding eBird applications specifically for research on birds that can be easily downloaded using smartphone apps. Smartphone applications in this research are used as a tool to download various applications, video recording, which is associated with rare endemic birds of West Java. Applications required in this study include bird morphology applications, application of bird behaviour (characteristics, voice, a way of flying, foraging and mating cycles), GPS imaging applications to illustrate migration patterns and video recording for analysis purposes. Advances in technology can assist in developing a field trip activities with various applications that are easily obtained online. For example, is the eBird application that can be used to study different types of birds by using a smartphone application. Studying the behavior of birds through some of the applications are available online at the moment is easy to obtain (Thomas, et al., 2017, 2016; Horton, et al,. 2014; Freeman, et al., 2016; Resheff, et al., 2014; Bom, et al., 2014; Boss, et al., 2016; Rubio, et al., 2016; Winger, et al., 2014; Harms, et al., 2014) studying the migration patterns of birds (Horton, et al,. 2014; Freeman, et al., 2016; Boss, et al., 2016; Gohli, et al., 2015; Rushing, et al., 2016; Zogaris, et al., 2016; Agostini, et al., 2016; 
Zuckerberg, et al., 2016; Miller, et al., 2016; Newson, et al., 2016) can also be used to study bird navigation (Freeman, et al., 2016; Orchan, et al., 2016; Gill, et al., 2015; Sjo'berg, et al., 2015; Gilroy, et al., 2016) it is beneficial for conservation efforts (Horton, et al,. 2014; Freeman, et al., 2016; Rosin, et al., 2016; Langham, et al., 2015; Newson, et al., 2016; 2016; Winger, et al., 2014).

In general, this study aims to describe the profile of field animal ecology activities, analyse student identification ability and student classification ability in field study activities and describe the use of smartphone application in field study activity. By studying the behaviour of birds based on their morphology using a smartphone app will make it easy for students to identify characteristics, a way of life, reproduction, adaptation and migration of rare birds such. With the provision of the identification of the students are expected to classify the rare birds are based on the differences, similarities, grouping criteria, contrasting characteristics and naming. By having the ability identification and classification, in future students are expected to contribute to the conservation efforts especially against rare birds endemic to West Java Indonesia general of endangered species.

\section{Method}

This research used a quasi-experimental design with randomised posttest only (Fraenkel, et al.1993). Data analysis techniques using quantitative descriptive techniques. The subjects are biology students in Pasundan University Bandung fifth semester on animal ecology class of 30 students. The sampling technique randomised sampling. Place of research conducted at the Universitas Pasundan.

\subsection{Data collection}

\subsubsection{Documentation}

Documentation was conducted to analyse the syllabus and RPS lab/field study activity in animal ecology lecture to describe the lecture, performance and materials related essential.

\subsubsection{Test}

The written test was conducted to determine the ability of identification and classification capabilities of students. Tests using ebird application on a smartphone.

\subsubsection{Questionnaires}

Questionnaires captured on student responses to the activities of field study and use of smartphones. 


\subsection{Statistical Analysis}

\subsubsection{Categories of student skills}

The identification and classification capability is analysed to determine its category. From the data collected in the study, then performed the analysis with technical analysis of quantitative descriptive which describes and interpret each component as compared to the reference criterion is based on the average score ideal (Mi) and the score of the standard deviation of the ideal ( $\mathrm{SBi}$ ) is achieved by a sheet instruments. This study uses a questionnaire scale of 5 with the conversion value and scores, determine (Mi) and (SBI) in this study using a formula developed by Jumadi (2012).

Table 1. Conversion score on a scale of 5

\begin{tabular}{cll}
\hline Numb. & Score & Criteria \\
\hline 1 & $x>(M i+1,8 S B i)$ & Excellent \\
2 & $(M i+0,6 S B i)<x<(M i+1,8 S B i)$ & Good \\
3 & $(M i-0,6 S B i)<x \leq(M i+0,6 S B i)$ & Sufficient \\
4 & $(M i-1,8 S B i)<x \leq(M i-0,6 S B i)$ & Deficient \\
5 & $x \leq(M i-1,8 S B i)$ & Lowest \\
\hline
\end{tabular}

\subsubsection{Correlation test}

Correlation test is used to determine the extent to which the relationship between the identification of the student classification capabilities. This is important because the ability of identification is the basis of the classification. Correlation test using $r$ test (Pearson correlation test).

\subsubsection{Questionnaire data}

Questionnaire data were analysed and then described based on the findings. Questionnaire data will give an overview on some of the findings in this study. This questionnaire is a response to the students about the learning activities and field trip activities on animal ecology class.

\section{Result and Discussion}

\subsection{Analysis of documentation}

Analysis of documentation made to the syllabus and RPS in the subject of animal ecology. Subject ecology animal weighs as much as three credits and one credit for practicum including college events field. Face to face organised 16 times face to face in one semester and one-times in one-week practicum, field study activities carried out one-time in the semester. Students 
involved are students of the fifth semester of biology education in the subject of animal ecology contained in the first semester, the student prerequisite to being able to sign this course must pass courses General Biology and Environmental Science.

The results of the analysis of RPS document on animal ecology courses provide information that the subject studied in this course are as follows:

1. Explain the concept of ecology and its constituent components

2. Identify the relationship between components of the ecology

3. Understand the legal minimum and tolerance, and its relation to the limiting factor

4. Analyze the distribution pattern of animals

5. Describe the animal in self-protection mechanism

6. Analyze strategies and foraging of animals

7. Understand the concept of habitats and niches

On this course, Learning Outcome (CPL) consists of two categories: CPL courses and subjects. CPL details can be seen in Table 2.

Table 2. CPL Course and Subject

\begin{tabular}{|c|c|c|c|}
\hline \multicolumn{2}{|c|}{ CPL Course } & \multicolumn{2}{|c|}{ CPL Subject } \\
\hline S6 & $\begin{array}{l}\text { Working together and have social } \\
\text { sensitivity and concern for people and the } \\
\text { environment }\end{array}$ & M1 & $\begin{array}{l}\text { Have competence mastery or } \\
\text { understanding of the basics, the essence } \\
\text { and purpose of the teaching profession } \\
\text { that accompanied the religious and } \\
\text { social attitudes inherent strong identity } \\
\text { as a professional teacher. }\end{array}$ \\
\hline S9 & $\begin{array}{l}\text { Show an attitude responsible for the } \\
\text { work in his field of expertise } \\
\text { independently }\end{array}$ & M2 & $\begin{array}{l}\quad \text { Able to apply mastery of the } \\
\text { concepts of biology and science } \\
\text { education in the current plan, } \\
\text { implement, evaluate and reflect on } \\
\text { learning independently and } \\
\text { responsibility by utilising science and } \\
\text { technology. }\end{array}$ \\
\hline P1 & $\begin{array}{l}\text { Being able to utilise relevant science } \\
\text { and technology education in the sphere of } \\
\text { biology to design, manage, implement, } \\
\text { evaluate and develop learning based }\end{array}$ & M5 & $\begin{array}{l}\text { Understanding how to research to } \\
\text { solve problems in the field of biology } \\
\text { education by utilising advances in } \\
\text { science and technology. }\end{array}$ \\
\hline
\end{tabular}

P2 Being able to use a variety of learning resources and learning media to support the recent biology curricular learning, curricular and extra-curricular

P3 Able to mastery the theoretical concepts and scientific principles of biology

KU1 Able to apply logical thinking, critical, systematic, and innovative in the context of the development or implementation of science and 


\begin{tabular}{ll}
\hline CPL Course & CPL Subject \\
\hline technology that observe and apply the \\
humanities value corresponding to their \\
expertise
\end{tabular}

\subsection{Identification Skills}

Identification skills in this report are focused on the identification of the morphology of birds and bird behaviour. Identification skills of students showed an average score of 2.68. To obtain information on the category of student identification capability, the analysis by using a conversion scale score of 5 , the results are presented in Table 3.

Table 3. Conversion of 5 Scale Score of Student's Identification Skills

\begin{tabular}{ccc}
\hline Numb. & Score & Criteria \\
\hline 1 & $x>3,01$ & Excelent \\
2 & $2,98<x<3,01$ & Good \\
3 & $2,53<x \leq 2,98$ & Sufficient \\
4 & $2,49<x \leq 2,53$ & Deficient \\
5 & $x \leq 2,49$ & Lowest \\
\hline
\end{tabular}

Based on Table 3. obtained information that the average score of 2.68 is in the range 2.53 to 2.98 , it can be concluded that the students' ability to identify the morphology of birds and bird behaviour included in the category sufficient. Thus, it will be a consideration in the development of the program of lectures, especially on the ability of the student identification, analyse shortcomings and methods/models should be used in the process of learning, especially practicum/field study activities.

Furthermore, this report analysed data for each indicator. It is intended to obtain information on the achievement of students to each indicator identification skills. Ability to identify this report consists of six indicators are accuracy (I-1), correlation (I-2), explanation (I-3), to formulate the problem (I-4), find the facts (I-5) and formulate problems (I-6). Each indicator analysis to obtain an average score. The results of the analysis of the data for each indicator is presented in Figure 1. 


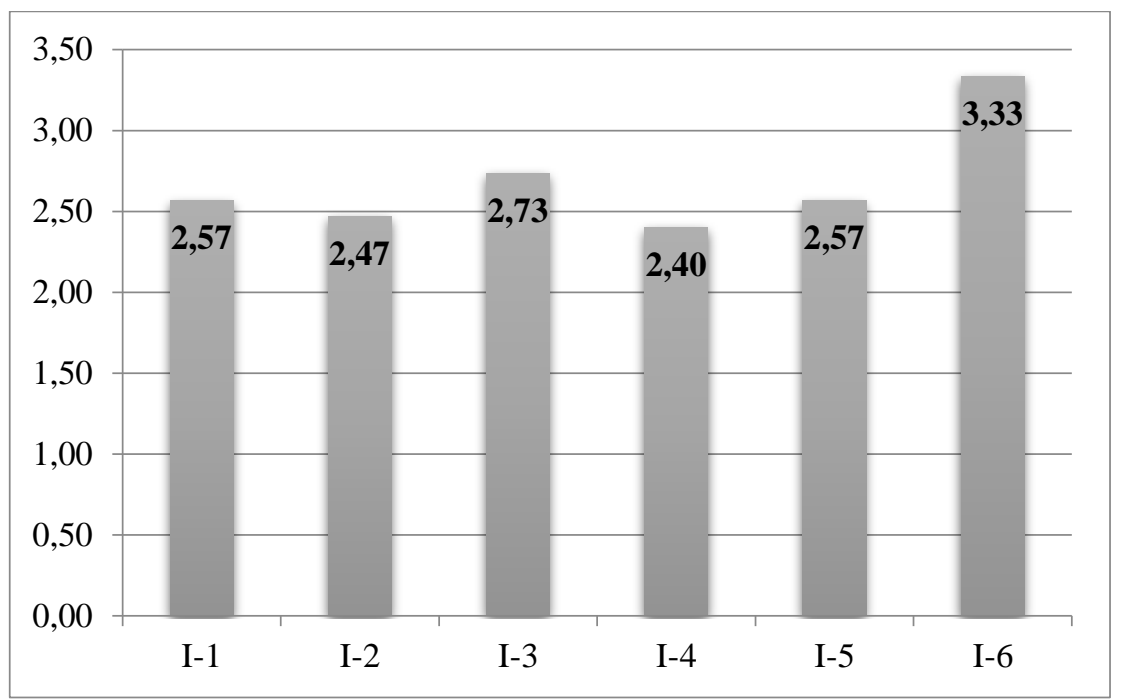

Figure 1. The Average Score Identification Skills of

Students for Each indicator

Based on Figure 1. obtained information that the identification of students based on the average of the indicator scores highest on the indicator 6 (I-6) that formulate the problem by 3.33. It can be concluded that the ability of the students well enough to formulate a problem related to the issue or facts that occur in the field. The indicator was lowest for the indicator 4 (I-4) is to formulate the problem at 2.40 . It can be concluded that the students' ability to formulate the problem is still very low, it is important to be improved and developed in the lecture program in the future.

\subsection{Classification Skills}

Classification Skills in this report also focused on the morphology of birds and bird behaviour. Classification Skills of students in this report shows the average score of 2.56. To obtain information about the category classification capabilities of students, then analysed using a conversion scale score of 5 , the results are presented in Table 4.

Table 4. Conversion of 5 Scale Score of Student's Classification Skills

\begin{tabular}{ccc}
\hline Numb. & Score & Criteria \\
\hline 1 & $x>2,84$ & Excelent \\
2 & $2,81<x<2,84$ & Good \\
3 & $2,39<x \leq 2,81$ & Sufficient \\
4 & $2,37<x \leq 2,39$ & Deficient \\
5 & $x \leq 2,37$ & Lowest \\
\hline
\end{tabular}


Based on Table 4. obtained information that the average score of 2.56 is in the range 2.39 to 2.81 , it can be concluded that the students' ability to classify birds based on the morphology of birds and bird behaviour included in the category sufficient. Thus it will be a consideration in the development of the program of lectures, especially on the ability of the student classification, analyse shortcomings and methods/models should be used in the process of learning, especially practicum/field study activities.

Furthermore, this report analysed data for each indicator classification capability. It is intended to obtain information on the achievement of students to each indicator of the ability of classification. Classification capability in this report consists of five indicators include: searching for similarities and differences (I-1), determine the criteria for grouping (I-2), describes the characteristics (I-3), specify the alternative grouping (I-4), and conclude (I-5). Each indicator analysis to obtain an average score. The results of the analysis of the data for each indicator is presented in Figure 2.

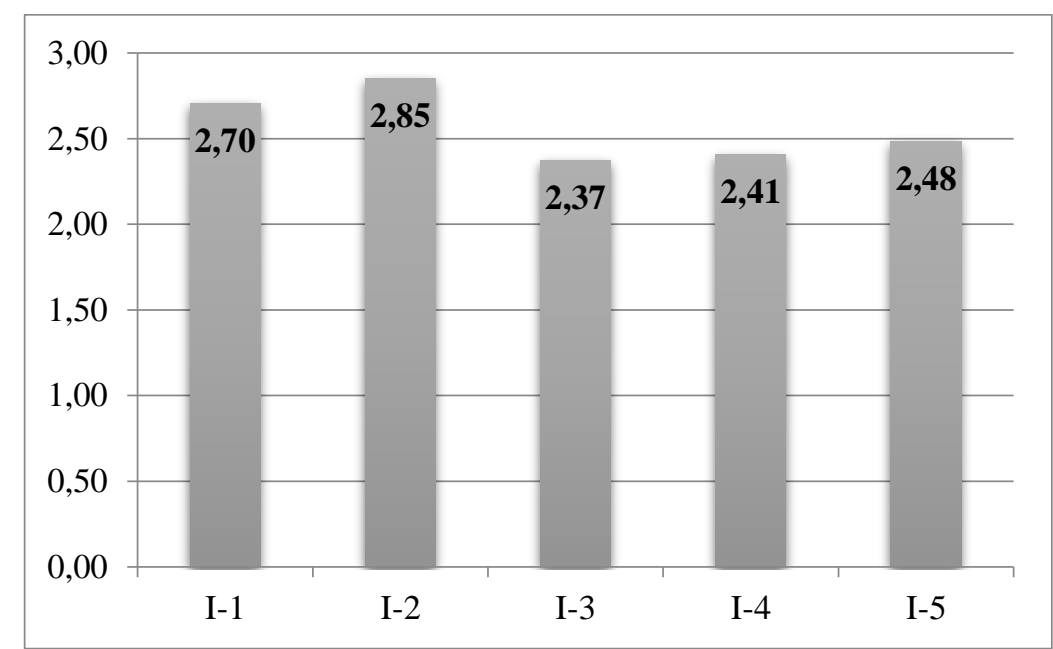

Figure 2. The Average Score Classification Skills of

Students for Each indicator

Based on Figure 2. obtained information that the identification of students based on the average of the indicator scores highest on second indicator (I-2) specify the criteria for grouping at 2.85. This shows the relationship where students can look for similarities and differences in the morphology of the birds will be able to determine the criteria for grouping. Both of these indicators have the highest average score among other indicators as indicators look for similarities and differences as well as determine the grouping criteria is an indicator that is quite 
easy. The average score was lowest for the third indicator (I-3), which describes the characteristics of birds based on morphology and behaviour typical of 2.37. This shows that the students' ability to explain any distinctive features associated morphology and perlikau birds is still very low. Thus these results provide information for consideration in the development of the program in the future related to learning, especially in the subject of animal ecology.

\subsection{Correlation Analysis}

Correlation analyses were conducted to determine the relationship between identification and classification skills of students in studying birds based on their morphology. Some assumptions suggest that the ability of identification is the basis of the ability of the classification, this shows that the two are mutually particulars ability closely with each other. To determine the relationship between the identification and classification skills using Pearson correlation test. Pearson correlation test results are presented in Table 5.

Table 5. Pearson correlation test

\begin{tabular}{llcl}
\hline & & Identification Skills & Classification Skills \\
\hline Identification & Pearson Correlation & 1 & -.107 \\
& Sig. (2-tailed) & & .574 \\
& $\mathrm{~N}$ & 30 & 30 \\
Classification & Pearson Correlation & -.107 & 1 \\
& & & \\
& Sig. (2-tailed) & .574 & 30 \\
\hline
\end{tabular}

Based on Table 5 was obtained that showed Pearson $r$ values -.107. Thus it can be concluded that there is no significant relationship between student identification and classification skills of students to learn birds based on their morphology. These results contrast with some assumption that the identification is a basis of classification skills. Thus this study should be analysed in what led to this bias occurs.

\subsection{Questionnaire}

Description of student responses on practicum/field trip activities and the use of smartphone applications on subjects Animal Ecology explored using a questionnaire instrument. Data from 40 student responses are presented in Table 6. 
Table 6. Data Questionnaire Responses Students

\begin{tabular}{|c|c|c|c|}
\hline \multirow[b]{2}{*}{ Numb } & \multirow{2}{*}{ Questionare } & \multicolumn{2}{|c|}{ Frequency } \\
\hline & & Yes & No \\
\hline 1 & $\begin{array}{l}\text { Do professors often use an experimental method in Animal Ecology field } \\
\text { trip/practice activities? }\end{array}$ & 31 & 9 \\
\hline 2 & Does using a guidebook for field trip/practice? & 40 & 0 \\
\hline 3 & $\begin{array}{l}\text { The guidebook given lecturers have a procedure that is easily understood } \\
\text { in the field trip/practice activities? }\end{array}$ & 23 & 17 \\
\hline 4 & Do professors use technology in the field trip/practice activities? & 4 & 36 \\
\hline 5 & $\begin{array}{l}\text { Whether to use technology based on information technology and } \\
\text { communication technology? }\end{array}$ & 3 & 37 \\
\hline 6 & $\begin{array}{l}\text { Do professors provide instruction for the use of smartphones in the field } \\
\text { study activities? }\end{array}$ & 0 & 40 \\
\hline 7 & $\begin{array}{l}\text { Do professors suggest some smartphone applications used in the field } \\
\text { trip/practice? }\end{array}$ & 0 & 40 \\
\hline 8 & $\begin{array}{l}\text { Do college field more frequent use of guide books on information } \\
\text { technology and technology kopmunikasi? }\end{array}$ & 40 & 0 \\
\hline 9 & $\begin{array}{l}\text { Have to use various features or applications in smartphones to support the } \\
\text { field trip/practice? }\end{array}$ & 2 & 38 \\
\hline 10 & $\begin{array}{l}\text { Do professors ever gives an example of using a variety of smartphone } \\
\text { applications in the field trip/practice activities? }\end{array}$ & 0 & 40 \\
\hline 11 & $\begin{array}{l}\text { Are you interested in the use of smartphone applications in the field } \\
\text { trip/practice activities? }\end{array}$ & 33 & 7 \\
\hline 12 & Do you have a smartphone? & 40 & 0 \\
\hline 13 & Can you operate the smartphone well? & 38 & 2 \\
\hline 14 & Have you ever use smartphone application for learning? & 12 & 28 \\
\hline 15 & $\begin{array}{l}\text { Do you think the use of smartphones is important in the field trip/practice } \\
\text { activities? }\end{array}$ & 37 & 3 \\
\hline
\end{tabular}

Point 1 explores a method often used by lecturers at college events field/lab, based on the responses of students indicate that the practicum/college field commonly used experimental method, it is certainly quite relevant given lab/lecture courts should have to use an experimental method, At point 2 explores the use of guidebooks on practicum/field study activities, based on the results of student responses indicate that the practicum/field study to fully use guidebooks. Item 3 explores the procedures used guidebooks, the results show that most of the procedures used in the guidebooks practicum/field study activities easily understood by students.

Item 4 through 15 on the questionnaire were exploring the use of technology in the practicum/field study. In point 4 of exploring the use of technology in the practicum/college field, the results show that the lecturers very rarely used the technology in the practicum/college field, it provides information that lecturers are still glued to the manual as a reference in carrying out these activities and generally lecturers using methods traditionally in practicum/field study. Item 5 explores related to the use of information technology and communication technology in the practicum/field study; the results show that the lecturers were very rarely using technology 
based on information technology and communication technology. Item 6 shows the faculty instruction related to the use of smartphones in the practicum/field study; the results show that the lecturer has never instructed the use of smartphones in the practicum/field study. In connection with point 6 , in point 7 explores the lecturer advice relating to use multiple applications in the use of smartphones, the results show that the lecturers would never suggest using some smartphone apps in the practicum/field study.

In item 8 explores the intensity of use of guidebooks and information technology and communication technology, the results show that the practicum/field study using guidebooks become the main reference in these activities compared to the use of information technology and communication technology. In item 9 explores the multiple features or applications smartphone Animal Ecology in the learning process in general, the results show that during the study, lab/lecture lecturer courts very rarely used features or applications in a smartphone in supporting the learning process and lab/lecture Animal Ecology field. At point 10 explores the ever whether or not the lecturer gives examples of the use of smartphone applications in the practicum/field study. The result showed that the professors never provide a variety of applications using current examples of smartphones in these activities.

Item 11 explores the interest of students to use the smartphone application in practical activities/field study; the results show the majority of students are interested in using the application smartphone on these activities, it should be realized considering the learning paradigm of the 21 st century has shifted to the use of technology one smartphone applications. Item 12 in the student explores smartphone ownership; the results show that all students have a smartphone. Of course, this is an opportunity pitch why not lecture/lab integrate smartphone apps in learning. Item 13 explores the students' ability to use/operate a smartphone; the results show that most students can operate the smartphone well. Of course, this is also an opportunity use of smartphones in learning.

Item 14 explore whether or not the smartphone app ever used in the learning, the results show that most students have never used a smartphone application in the learning process. It is quite unfortunate given some pretty decent smartphone applications in use in learning, especially concerning animal ecology with features that are easily available online. Item 15 explored whether or not the practicum/field study using smartphone applications; the results show that most students regard the use of smartphone applications in these activities is 
important to use. Based on analysis of student questionnaires, it can be used as a reference in the development of a program to integrate technology in learning or practicum/field study.

In the process of learning in the 21 st century is very important to integrate the advancement of science and technology in the field of science whatsoever. Advances in science and technology can serve as a pretty good support for learning. Field trip or lab activity at this time is not yet fully using advances in science and technology, especially advances in information technology and communication technology. One example is the smartphone application. Growing smartphone application equipped with features more sophisticated along with some applications that can easily be obtained online. This is an opportunity to create a new method/model/approach to learning. We know that at this time all students have a smartphone with some applications, this should be utilised in the learning process.

\subsection{Recommendation Program Design}

Based on the analysis, the authors saw their chances of implementation of technology-based Smartphone applications in the practicum/field study and learning in general. The program design is presented in Figure 3.

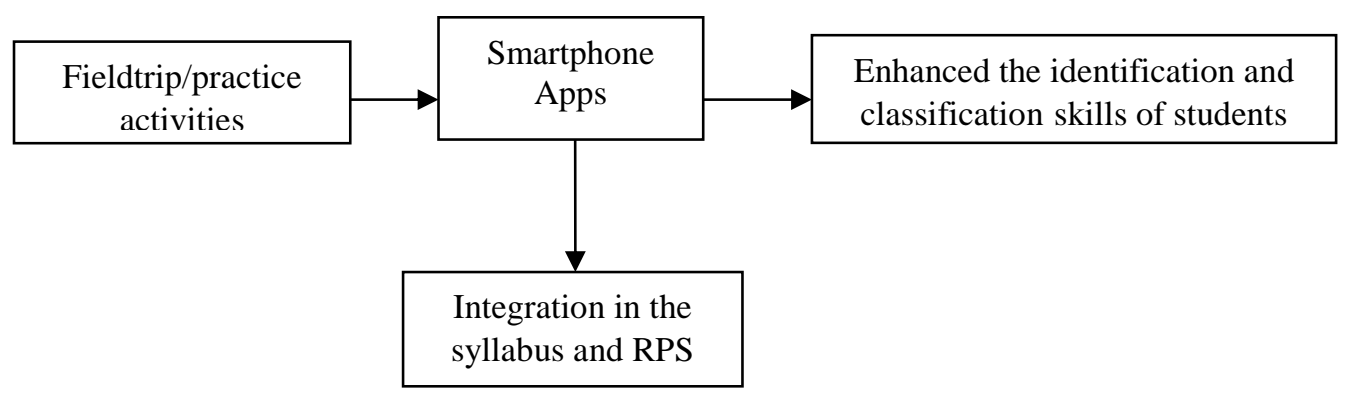

Figure 3. The design of Animal Ecology Class Development Program

Based on Figure 3. The program design field lecture/lab begins with application integration smartphone in the syllabus as well as RPS, which is focused on improving the ability of identification and classification capabilities of students. Ability to identify important possessed by students at college events field in particular. Besides contributing instructional lab activities in animal ecology should be able to grow in the development of conceptual thinking ability, the imagination, stimulate the desire and sharpness honed methodological experiment as part of the experience, increase scientific reasoning and develop critical thinking skills. Practicum is a 
laboratory of practical activities that include demonstration activities and experiments that produce learning experience, explore the identification and classification capabilities.

Therefore, based on the results of this field study, suggested some program design include:

1. Model technology-based learning IT / ICT

Should the trend of the 21st-century instructional use of IT / ICT be put forward in the learning process? IT technology / ICT can be integrated into the syllabus or RPS to be further developed in particular.

2. The use of smartphone apps in the practicum/field study.

The rapid development of smartphone technology with its features are more sophisticated than before. Of course, this can be used as an opportunity to apply the learning process. E-Bird, one of the main examples of applications that can be used to study the birds, can easily be downloaded online.

\section{Conclusion}

Based on the analysis of documents and the questionnaire responses of students it can be concluded that the RPS at CPL course and CPL subject irrelevant to reality, it is shown that the CPL course and CPL subject mention of the use of science and technology, the application of science and technology and to use advances in science and technology is inversely proportional to the questionnaire responses of students. Thus concluded that the use of science and technology in Animal Ecology lectures have not been applied in the learning process or practicum/field study. Based on the results of data analysis identification and classification skills of students showed that students' ability of identification and classify birds based on morphological grooming behaviour is included in the category sufficient. Thus it will be a consideration in developing the company's program, especially in animal ecology course on the future. Analysis of the relationship between the identification and classification skills of students showed no significant relationship; it is contrary to some assumptions that state that the ability to identify a basis for classification capability. Furthermore, based on the analysis of questionnaires students, in general, it can be concluded that learning by using new methods, in this case, using a smartphone application in practical activities/field study should be considered to be tested and developed. 


\section{References}

Agostini, N., Gustin, M., von Hardenberg, J., \& Panuccio, M. (2016). Wind patterns affect migration flyways and flock size of a soaring bird over sea. Avian Biology Research, 9(3), 159-166. DOI: 10.3184/175815516X14627928448105.

Beri, P. S., Dawande, P. A., Eksambekar, R. A., Gokhale, R. A., \& Sonawani, M. S. S. (2016). Migratory Birds Tracking System using RF as Communication Medium and Android Mobile Base Station. International Journal on Recent and Innovation Trends in Computing and Communication, 4(5), 543-545. Available online: https://www.research gate.net/profile/Puneet_Beri2/publication/313646333_Migratory_Birds_Tracking_Syste m_using_RF_as_Communication_Medium_and_Android_Mobile_Base_Station/links/5 8a15411aca272046aad6af4/Migratory-Birds-Tracking-System-using-RF-asCommunication-Medium-and-Android-Mobile-Base-Station.pdf

Bom, R. A., Bouten, W., Piersma, T., Oosterbeek, K., \& van Gils, J. A. (2014). Optimizing acceleration-based ethograms: the use of variable-time versus fixed-time segmentation. Movement Ecology, 2(1), 6. Avaliable online: https://movementecologyjournal .biomedcentral.com/articles/10.1186/2051-3933-2-6

Boss, J., Liedvogel, M., Lundberg, M., Olsson, P., Reischke, N., Naurin, S., ... \& Bensch, S. (2016). Gene expression in the brain of a migratory songbird during breeding and migration. Movement ecology, 4(1), 4 DOI: 10.1186/s40462-016-0069-6

Bouten, W., Baaij, E. W., Shamoun-Baranes, J., \& Camphuysen, K. C. (2013). A flexible GPS tracking system for studying bird behaviour at multiple scales. Journal of Ornithology, 154(2), 571-580. DOI: 10.1007/s10336-012-0908-1

Bridget J. M., et al. 2016. Ecological causes and consequences of intratropical migration in temperate-breeding migratory birds. The American Naturalist, 188(S1), S28-S40. DOI: $10.1086 / 687531$.

Dodge, S., Bohrer, G., Weinzierl, R., Davidson, S. C., Kays, R., Douglas, D., ... \& Wikelski, M. (2013). The environmental-data automated track annotation (Env-DATA) system: linking animal tracks with environmental data. Movement Ecology, 1(1), 3. Available online: https://movementecologyjournal.biomedcentral.com/articles/10.1186/20513933-1-3. 
Fayet, A. L., Freeman, R., Shoji, A., Boyle, D., Kirk, H. L., Dean, B. J., ... \& Guilford, T. (2016). Drivers and fitness consequences of dispersive migration in a pelagic seabird. Behavioral Ecology, 27(4), 1061-1072. DOI:10.1093/beheco/arw013. 2016.

Fraenkel, et al. 1993. How to Design and Evaluate Research in Education. Eighth Edition. United States: The McGraw-Hill Companies, Inc.

Freeman, R., Dean, B., Kirk, H., Leonard, K., Phillips, R. A., Perrins, C. M., \& Guilford, T. (2013). Predictive ethoinformatics reveals the complex migratory behaviour of a pelagic seabird, the Manx Shearwater. Journal of the Royal Society Interface, 10(84), 20130279. DOI: $10.1098 /$ rsif.2013.0279

Friggens, M. M., et al. 2015. Implications of Climate Change for Bird Conservation in the Southwestern U.S. under Three Alternative Futures. Plos One. DOI:10.1371/journal.pone.0144089.

Galvis, M. A. E., et al. 2013. Flight Performance and Feather Quality: Paying the Price of Overlapping Moult and Breeding in a Tropical Highland Bird. Plos One. 8 (5). e61106. DOI:10.1371/journal.pone.0061106.

Gill, J. A., et al. 2015. Why is timing of bird migration advancing when individuals are not? The Royal Society Publishing. DOI: 10.1098/rspb.2013.2161

Gilroy, J. J., Gill, J. A., Butchart, S. H., Jones, V. R., \& Franco, A. (2016). Migratory diversity predicts population declines in birds. Ecology letters 19(3): 308-317. DOI: 10.1111/ele.12569.

Gohli, et al. 2015. Migration distance is positively associated with sex-linked genetic diversity in passerine birds. Ethology Ecology \& Evolution. DOI: 10.1080/03949370.2015.1018954.

Harel, L., et al. 2016. Decision-making by a soaring bird: time, energy and risk considerations at different spatio-temporal scales. The Royal Society Publishing, http://dx.doi.org/10.1098/rstb.2015.0397.

Harms, N. J., et al. 2014. Feather corticosterone reveals effect of moulting conditions in the autumn on subsequent reproductive output and survival in an Arctic migratory bird. The Royal Society Publishing. http://dx.doi.org/10.1098/rspb.2014.2085.

Hobson, K., Van Wilgenburg, S., Dunn, E., Hussell, D., Taylor, P., \& Collister, D. (2015). Predicting origins of passerines migrating through Canadian migration monitoring stations using stable-hydrogen isotope analyses of feathers: a new tool for bird 
conservation. Avian Conservation and Ecology, 10(1). Available online: http://www.aceeco.org/vol10/iss1/art3/

Horton, T. W., Bierregaard, R. O., Zawar-Reza, P., Holdaway, R. N., \& Sagar, P. (2014). Juvenile osprey navigation during trans-oceanic migration. PloS one, 9(12), e114557. DOI:10.1371/journal.pone.0114557

Jumadi 2012. Pemetaan Kompetensi Pedagogik, Profesional, Kepribadian dan Sosial Guru Fisika SMA/MA di Daerah Istimewa Yogyakarta. (Makalah). LPPKM UNY. Tidak diterbitkan. Avalilable online: http://eprints.uny.ac.id/23362/

Kelly, J. F., Horton, K. G., Stepanian, P. M., Beurs, K. M., Fagin, T., Bridge, E. S., \& Chilson, P. B. (2016). Novel measures of continental-scale avian migration phenology related to proximate environmental cues. Ecosphere, 7(8). Available online: http://onlinelibrary.wiley.com/doi/10.1002/ecs2.1434/full

Langham, G. M., Schuetz, J. G., Distler, T., Soykan, C. U., \& Wilsey, C. (2015). Conservation status of North American birds in the face of future climate change. PloS one, 10(9), e0135350. DOI:10.1371/journal.pone.0135350.

Laughlin, A. J., et al. 2016. Quantifying non-breeding season occupancy patterns and the timing and drivers of autumn migration for a migratory songbird using Doppler radar. Ecography, 39: 001-008, 2016. DOI: 10.1111/ecog.01988.

Lewis, L. R., Behling, E., Gousse, H., Qian, E., Elphick, C. S., Lamarre, J. F., ... \& Goffinet, B. (2014). First evidence of bryophyte diaspores in the plumage of transequatorial migrant birds. PeerJ, 2, e424. DOI: 10.7717/peerj.424.

Mallory, M. L., Little, C. M., Boyd, E. S., Ballard, J., Elliott, K. H., Gilchrist, H. G., ... \& Shutler, D. (2015). Leucocyte profiles of Arctic marine birds: correlates of migration and breeding phenology. Conservation physiology, 3(1), cov028. DOI: 0.1093/conphys/cov028

Mellone, U., et al. 2015. Seasonal differences in migration patterns of a soaring bird in relation to environmental conditions: a multi-scale approach. Behav Ecol Sociobiol 69:75-82. DOI 10.1007/s00265-014-1818-4.

Miller, R. A., et al. 2016. Local and regional weather patterns influencing post-breeding migration counts of soaring birds at the Strait of Gibraltar, Spain. Ibis 158: 106-115. Available online: http://onlinelibrary.wiley.com/doi/10.1111/ibi.12326/full 
Nelson, A. R., et al. 2016. Migration patterns of San Francisco Bay Area Hermit Thrushes differ across a fine spatial scale. Animal. Migration, 3:1-13 Available online: http://userwww.sfsu.edu/sehgal/Publications_files/Nelson\%20et\%20al\%20hermit\%20th rushes\%202016.pdf

Newson, S. E., Moran, N. J., Musgrove, A. J., Pearce-Higgins, J. W., Gillings, S., Atkinson, P. W., ... \& Baillie, S. R. (2016). Long-term changes in the migration phenology of UK breeding birds detected by large-scale citizen science recording schemes. Ibis, 158(3), 481-495. Available online: http://onlinelibrary.wiley.com/doi/10.1111/ibi.12367/full

Orchan, Y., Ovaskainen, O., Bouten, W., \& Nathan, R. (2016). Novel Insights into the Map Stage of True Navigation in Nonmigratory Wild Birds (Stone Curlews, Burhinus oedicnemus). The American Naturalist, 187(6), E152-E165. DOI: 10.1086/686054.

Penuela, N. O., et al. 2016. Patterns of bird-window collisions inform mitigation on a university campus. PeerJ. DOI 10.7717/peerj.1652

Resheff, Y. S., et al. 2014. AcceleRater: a web application for supervised learning of behavioral modes from acceleration measurements. Movement Ecology. V. 2 No. 27. p1-7. DOI 10.1186/s40462-014-0027-0.

Robinson, B. S., et al. 2016. A Rose by Any Other Name: Plant Identification Knowledge \& Socio-Demographics. Plos One. DOI:10.1371/journal.pone.0156572

Robles, M. R., et al. 2016. Temporal changes in the structure of a plant-frugivore network are influenced by bird migration and fruit availability. PeerJ. DOI: 10.7717/peerj.2048.

Rosin, Z. M., et al. 2016. Constant and seasonal drivers of bird communities in a wind farm: implications for conservation. PeerJ. DOI: 10.7717/peerj.2105.

Rubio, M. S., et al. 2016. Forest birds respond to the spatial pattern of exurban development in the Mid-Atlantic region, USA. PeerJ. DOI: 10.7717/peerj.2039.

Rushing, C. S. et al. 2016. Quantifying drivers of population dynamics for a migratory bird throughout the annual cycle. The Royal Society Publishing. DOI: /10.1098/rspb.2015.2846.

Saino, N., et al. 2015. Polymorphism at the Clock gene predicts phenology of long-distance migration in birds. Molecular Ecology, 24: 1758-1773. DOI: 10.1111/mec.13159. 2015. 
Schuld, C., et al. 2015. International standards for neurological classification of spinal cord injury: classification skills of clinicians versus computational algorithms. Spinal Cord. (2015) 53, 324-331 Avaliable online: https://www.nature.com/articles/sc2014221

Sjo'berg, S., et al. 2015. Nocturnal migratory songbirds adjust their travelling direction aloft: evidence from a radiotelemetry and radar study. The Royal Society Publishing. DOI: $10.1098 /$ rsbl.2015.0337

Sorte, F. A. L., Fink, D., Hochachka, W. M., DeLong, J. P., \& Kelling, S. (2013). Populationlevel scaling of avian migration speed with body size and migration distance for powered fliers. Ecology, 94(8), 1839-1847. Available online: http://onlinelibrary.wiley.com/doi/10.1890/12-1768.1/full

La Sorte, F. A., Fink, D., Hochachka, W. M., Farnsworth, A., Rodewald, A. D., Rosenberg, K. V., ... \& Kelling, S. (2014). The role of atmospheric conditions in the seasonal dynamics of North American migration flyways. Journal of Biogeography, 41(9), 1685-1696. DOI:10.1111/jbi.12328.

Sorte, F. A. L., et al. 2016. Spring phenology of ecological productivity contributes to the use of looped migration strategies by birds. The Royal Society Publishing, DOI: 10.1098/rspb.2014.0984.

Soto, R., Crawford, B., Almonacid, B., \& Paredes, F. (2016). Efficient parallel sorting for migrating birds optimization when solving machine-part cell formation problems. Scientific Programming, 2016:1-39 DOI: 10.1155/2016/9402503.

Stutchbury, B. J., Fraser, K. C., Silverio, C., Kramer, P., Aeppli, B., Mickle, N., .. \& Mejeur, J. (2016). Tracking mated pairs in a long-distance migratory songbird: migration schedules are not synchronized within pairs. Animal Behaviour, 114, 63-68. Available online: http://www.sciencedirect.com/science/article/pii/S0003347216000191

Supp, S. R., Sorte, F. A. L., Cormier, T. A., Lim, M. C., Powers, D. R., Wethington, S. M., ... \& Graham, C. H. (2015). Citizen-science data provides new insight into annual and seasonal variation in migration patterns. Ecosphere, 6(1), 1-19. Available online: http://onlinelibrary.wiley.com/doi/10.1890/ES14-00290.1/full

Surasinghe, T., \& Courter, J. (2012). Using eBird to Integrate Citizen Science into an Undergraduate Ecology Field Laboratory. Bioscene: Journal of College Biology Teaching, 38(2), 16-20. Available online: https://eric.ed.gov/?id=EJ1002149 
Thomas, R. L., \& Fellowes, M. D. (2017). Effectiveness of mobile apps in teaching field-based identification skills. Journal of Biological Education, 51(2), 136-143. DOI: 10.1080/00219266.2016.1177573

Vágási, C. I., Pap, P. L., Vincze, O., Osváth, G., Erritzøe, J., \& Møller, A. P. (2016). Morphological adaptations to migration in birds. Evolutionary Biology, 43(1), 48-59. DOI: $10.1007 / \mathrm{s} 11692-015-9349-0$.

Weimerskirch, H., et al. 2012. Changes in Wind Pattern Alter Albatross Distribution and LifeHistory Traits. Science, V. 335, 211 (2012), DOI: 10.1126/science.1210270.

Winger, B. M., Barker, F. K., \& Ree, R. H. (2014). Temperate origins of long-distance seasonal migration in New World songbirds. Proceedings of the National Academy of Sciences, 111(33), 12115-12120. Available online: http://www.pnas.org /content/111/33/12115.short

Zogaris, S., et al. 2016. Coastal zone habitat-use by birds in Qatar: Insights from a rapid assessment method during spring migration. Tropical Conservation Science, Vol. 9 (2): 658-676. Available online: http://journals.sagepub.com/ doi/abs/10.1177/194008291600900207

Zuckerberg, B., et al. 2016. Novel seasonal land cover associations for eastern North American forest birds identified through dynamic species distribution modeling. Diversity and Distributions, (Diversity Distrib.) 22: 717-730. DOI: 10.1111/ddi.12428. 